\title{
Kadın Kimlik Mekân: Sex And The City 2 Filminde Süper Kadın Kimliği
}

\author{
Muhsine SEKMEN ${ }^{1}$ ve Aslı YURDİGÜL ${ }^{2}$
}

$\ddot{O} z$

Kimlik, bireye toplum tarafindan dayatılan ve birey tarafindan kabul görerek içselleşen bir alg1 formudur. Erkeğin ayrıcalıklı kimliğe sahip olması, kadının ise ondan daha aşă̆ı ve daha az haklara sahip kimlik unsurlarıyla kuşatılması feminist paradigmanın problematik alanında yer almaktadır. Kadına ve erkeğe dayatılan bu kimlik sürecinin ise mekân ile ayrılmaz bir ilişkisi bulunmaktadır. Bu çalışma kadın kimliğinin oluşmasında mekânı ön planda tutarak, süper kadın kimliği üzerinden incelemeyi amaçlamaktadır. Çalışmada, Michael Patrick King tarafindan yönetilen ve 2010 tarihinde gösterime giren Sex and the City 2 filmi inceleme alanı olarak seçilmiş ve bu filmde yer alan dört kadın karaktere 'süper kadın’ kimliği üzerinden niteliksel analiz yapılmıştır. Çalışma, filmdeki kadın kimliği ve mekân arasındaki ilişkiyi liberal feminist medya çalışmaları temelinde ele almaktadır. Çalışmada süper kadın kimliği, kadın-kimlik ve mekân ilişkileri çerçevesinde değerlendirilmiştir. Bu değerlendirmede New York ve Abu Dabi şehirleri kadın kimliğini belirleyen temel mekânlar olarak kabul edilmiş ve iki şehir arasındaki kadın kimlikleri ve davranış şekilleri incelenmiştir. Çalışmada elde edilen bulgular neticesinde New York ve Abu Dabi şehirlerinde yaşayan kadın kimliklerinin inşa edilmesinde mekân unsurunun ön planda olduğu ortaya çıkarılmıştır. Bunun yanında filmde kadınların her ne kadar Süper Kadın olarak sunulmasına karşın, filmin alt metninde Castells’in meşrulaştırıcı kimlik unsuru içine yerleştirilmesi dikkat çekmektedir.

Anabtar Kelimeler: Kadın, Kimlik, Mekân, Süper Kadın

\section{Woman Identity and Space: Superwoman Identity in Sex and The City 2}

\section{Abstract}

Identity is a sense of perception that is imposed by society and internalized by an individual who accept it. It is in the problematic field of the feminist paradigm in which the man has a privileged identity and the woman is surrounded by identity elements with lower position and fewer rights than men have. This identity process imposed on women and men has a direct relationship with space. This study tries to analyse the identity of the woman with the identity of "Super Woman" by prioritizing the concept of space. This study aims to conduct a qualitative analysis of the four female characters through the identity of Super Woman in Sex and the City 2, the movie directed by Michael Patrick King and released in 2010.This study handles the relationship between the woman identity and space in the movie on the basis of feminist media studies. In this study, superwoman identity was evaluated within the framework of woman-identity and space relations. In this evaluation, the cities of New York and Abu Dhabi were the main places that determine women's identity and their identities and the ways of behaviour and identities in the two different cities were examined. As a result, this study shows that space has great importance for woman identity formation. Besides, it is noteworthy that woman identity is situated in Castell's concept of legitimizing identity although women are presented as Superwomen in the movie.

Key Words: Women, Identity, Space, Superwomen

\section{Atıf İçin / Please Cite As:}

Sekmen, M. ve Yurdigül, A. (2021). Kadın kimlik mekân: Sex And The City 2 filminde süper kadın kimliği. Manas Sosyal Arasttrmalar Dergisi, 10(1), 422-436.

Geliş Tarihi / Received Date: 16.08.2020

Kabul Tarihi / Accepted Date: 29.10.2020

\footnotetext{
${ }^{1}$ Dr. Öğr. Üyesi - Atatürk Üniversitesi İletişim Fakültesi, muhsine.sekmen@atauni.edu.tr

(iD) ORCID: 0000-0001-5493-9927

${ }^{2}$ Doç. Dr. - Atatürk Üniversitesi / Kırgızistan-Türkiye Manas Üniversitesi İletişim Fakültesi, asli.yurdagul@hotmail.com

(i) ORCID: 0000-0001-5333-9751
} 


\section{Giriş}

Kadın, kimlik ve mekân ilişkisini süper kadın kimliği üzerinden inceleyen bu çalışma, kadın kimliğinin belirlenmesi noktasında mekân unsurunun önemine vurgu yapmaktadır. Kadın ve erkek kimliğin özneyi konumlandıran mekân ile ayrılmaz bir ilişkisi bulunmaktadır. Feminist çalışmaların itici gücünü oluşturan liberal feminizm, kadının ev içi alandan uzaklaşarak kamusal alana açılmasını amaçlamaktadır. Bu kapsamda liberal feminist medya çalışmalarına ticari kültürün verdiği bir yanıt olarak görülen süper kadın kimliği; ev ve iş yaşamını bir arada ve başarıyla götüren, tek başına ayakları üstünde durabilen kadınlar olarak inşa edilmiştir. Liberal feminist paradigmaya göre kadın, erkeklerle aynı çalışma koşullarında yer almalı ve güçlü kadın haline dönüşmelidir.

Bu çalışmada kadının kimlik inşası "Sex and the City 2" (Michael Patrick King, 2010) filmi üzerinden mekânla olan ilisskisi bağlamında incelenmektedir. Film, süper kadın kimliğinin kurucu unsuru olarak özgür ve güçlü kadın imgesini iki farklı mekân olan New York ve Abu Dabi şehirleriyle bağlantılı olarak sunmaktadır. Filmde New York’ta mekâna bağlı olarak inşa edilen özgür kadın kimliği ön plana çıarken; Abu Dabi'de bu kimlikle olan farklılıkları üzerinden Müslüman Arap kadın kimliği tanımlanmaktadır. Mekâna bağlı olarak ortaya çıkan bu kimlikler karakterlerin davranış örüntülerinde de kendini göstermektedir. Çalışma, söz konusu filmde mekâna bağlı olarak ortaya çıkan süper kadın imgesini ele almaktadır. Bu çerçevede, filmde sunulan kadın kimlikleri öncelikle New York ve Abu Dabi şehirleri üzerinden, sonrasında da bu şehirlerin mekânsal temsilleri olan ev içi mekânlar, iş yaşamına ait mekânlar, alısveriş mekânları ve bu mekânlara bağlı olarak ortaya çıkan farklı kadın kimlikleri üzerinden tartışılmaktadır.

\section{Kadın, Kimlik ve Mekân}

Kimlik kavramı, kişinin kendi dışında toplum tarafından oluşturulmuş algının kişi tarafindan içselleştirilmesini ifade etmektedir (Assmann, 2001, s. 130). Burada önemli olan, kişinin dişında oluşturulan bu algının fark edilmeden kişi tarafından içselleştirilmesidir. Kimlik, kişinin kendisini tanımlayarak bağlı olduğu 1rk, kültür, milliyet ve cinsiyet gibi bileşenlere ayrılmaktadır. Bu anlamda kimliği toplumsal yap1 içinde yer alan aktörlerin kendilerini tanımlamada başvurdukları bir anlam kaynağı olarak görmek gerekmektedir. Yani kimlik, bireyin dışında belirlenmiş bir anlam kaynağı olmasıyla iktidara gönderme yapmaktadır. Buradan hareketle kimlik, üç farklı biçimde oluşmaktadır (Castells, 2008, s. 13-14);

1. Meşrulastrnc Kimlik: Toplumun egemen kurumları tarafından toplumsal aktörlerin uyması için tasarlanan kimliktir. Bu kimlik, iktidarın kendi hegemonyasını genişletmesine yardımcı olmaktadır.

2. Direniş Kimliği: Toplumdaki egemen kurumlar tarafindan değersiz görülen aktörlerin geliştirdiği kimlik politikasıdır.

3. Proje Kimliği: Toplumsal aktörlerin toplumsal yapıda değişiklik yaparak toplumsal konumlarını değiştirmeyi planladıkları kimlik biçimidir. Feministlerin, kadınların toplumsal konumları ile ilişkili değişiklikler proje kimliği içinde değerlendirilmektedir.

Castells kimliği açıklarken ve farklı biçimlerde tezahürlerini tanımlarken, egemen kurumsal yapıları merkezi bir konuma yerleştirmektedir. Tipkı Fransız İhtilali ile birlikte Fransa'da boy gösteren Marianne heykeli gibi. Marianne heykelinde kadınlar, ulusal kültürün taşıyıcıları olarak görülmekte ve anne kimliği ile tanımlanmaktadır. Marianne ideal yurttass sureti ile toplumun farklı kesimlerinde yer alan insanları birleştirici bir unsur olarak görülmektedir. Clement’in resminde Marianne, süt dolu göğüsleri ile Fransızları besleyeceği iması yer almaktadır. Bu temsil, devrimci devletin bir yurtseverlik görevi olarak tıpkı bir anne gibi çocuklarına bakacağına işaret etmektedir (Sennett, 2011, s. 255-261). Ulus devlet sürecinde kadına yüklenen bu annelik vasfı, zamanla kadın kimliğinin ana bileşeni haline gelmektedir. Bu bağlamda kadının geleneksel ataerkil toplumlardan modern ulus devlete kadar kimlik kazanma sürecinde annelik, değişmeyen bir kimlik öğesi olarak dikkat çekmektedir.

Kadın kimliğinin sinemada mekânsal konumunu inceleyen bu çalışmada kadın kimliği, meşrulaştırıcı kimlik kategorisi içinde değerlendirilmektedir. Çünkü sinemada inşa edilen kadın kimliği, erkek egemen kapitalist sistemin kadını görme biçimini ifade etmektedir. Feminist film eleştirisi de bu bakış açısını eleştirerek kadınların kendilerine ait bir anlamlandırma sistemi içinde değil, erkek bakış açısından inşa edilerek sunulduğunu ileri sürmektedir (Özden, 2004, s. 194). Genel anlamda, medyada da kadın kimliği temsil edilirken erkek bakış açısından ve erkeğin kadını görme biçimi üzerinden temsil edilmektedir. $\mathrm{Bu}$ nedenle meşrulaştırıı kimlik erkeğin kadını görme biçimi olarak ortaya çıkmaktadır. 
Hall'e göre kimlik eylemin zeminidir (1998, s. 64). Yani, kimlik eylemde bulunurken eylemin yapıldığ1 mekâna gönderme yapmaktadır. Kimliğin ötekinin konumundan anlatıldĭğn ifade eden Hall, (1998, s. 72) kimliğin ben-öteki karşıtlığı içinden, ötekinin konumu üzerinden belirlendiğini vurgulamaktadır. Kadın kimliğinin toplumsal inşaya dayalı kurulmasında erkeğin bakış açısıyla kadını tanımlama niteliği açığa çıkmaktadır.

Modern kimlikler, bireyin varlığını ve eyleminin žeminini oluşturarak bireye hayatı ile ilişkili kesinlik ve mutluluk vermektedir (Özyurt, 2005, s. 194). Bireyin benlik ve öteki, özne ve nesne belirsizliklerini ortadan kaldırarak onu belirli bir mekâna yerleştirmekte ve güvence altına almaktadır. Bu anlamda modern kimlik, bireyden önce var olan kimliğin tercih etmesiyle gerçekleşmektedir.

Feminizmin temel problematik alanında mekân unsuru olarak ev yer almaktadır. Ev, her şeyden önce aileyi için alan, ilisskisel bir mekândır. Ev, kadın ve kadınlıkla ilişsilendirilirken; erkek, ücretli emek ile ilişkilendirilmektedir (Davidoff, 2016, s. 106). Bu durumda özel alan ev ile yani kadınla, kamusal alan ise erkek ile bağ kurularak aktarılmaktadır. Fransız feminist Simone de Beauvoir "özel olan politiktir" ifadesiyle, kadınların ev içi yaşamda maruz kaldıkları sorunların tekil olmadığını, aslında tüm kadınların benzer sorunları yaşadıklarını ifade etmektedir. Böylece tüm kadınların sorunlarını kamusal mecraya taşıyarak bu sorunlanı aşabilecekleri üzerinde durmaktadır. Beauvoir, kadınların ev ile ilişkili yaşamını "öz̧el olan politiktir" söylemiyle açıklarken, kadının ev yaşamından dış dünyaya açılımının da bir yolu olarak görmektedir. Yani, özel ve kamusal alan arasındaki sınırların kalkması kadın sorununun çözümü için ciddi bir aşama olarak kabul edilmektedir. Bu durum, iktidar ilişkileri ile tanımlanan kamusal dünya ile ilişkilerin doğal ya da politik olarak önemsiz kabul edildiği özel dünya arasındaki yapay sınırların ortadan kaldırılmasının önünü açmaktadır (Weeks, 2012, s. 111).

Walby ataerkilliği özel ataerkillik ve kamusal ataerkillik olmak üzere iki biçimde kategorize etmektedir. Özel ataerkillik, kadının ev halkına ve ev reisi olan erkeğe hizmet etmesini ve onun kamusal alandan dışlanmasını ifade etmektedir. Kamusal ataerkillik ise kadınların kamusal alanda var olmalarına izin vermekle birlikte, onların bu alanda ezilmelerine işaret etmektedir. Walby'e göre toplum, özel ataerkillikten kamusal ataerkilliğe geçmiş durumdadır (Akt: Kandiyoti, 2011, s.164). Sonuç olarak ataerkillik, toplumsal yap1 değiştikçe kendisini farklı bir görünümde sunmaktadır. Ataerkilliğin bu değişen görünümü, sinemada da kadını görme biçiminde farklılığa neden olmaktadır. Bu durumda kadınların Hollywood sinemasındaki temsiline bakmak gerekmektedir.

\section{Hollywood Sinemasında Kadın ve Kimlik}

Hollywood sinemasında 70’ler ve 80’ler feminizmin sinemada yansımasının görüldüğü yıllardır. Kadın yönetmenler filmlerinde kadınları bağımsız temsil etmeye çalısmasına rağmen, erkek yönetmenler kadınları eve ve erkeğe bağımlı olarak göstermeye çalışışlardır. Hatta 80'lerin başlarında aile filmlerinde kadınları cezalandırmak için aile babası erkek imgelerine sıkça yer verilmiştir. Bu durumda evden giden kadınlar ya yuva yıkan kadın olarak temsil edilmekte ya da yeni noir tary örümcek kadın olarak gösterilmekteydi (Ryan Kellner, 2010, s. 218). Aslında bu konular aracılı̆̆ılla, bu dönemde iş yaşamına girmeye çalışan kadınlara birtakım uyarılar yapılması söz konusuydu. Filmlerde evden çıkan kadın, yuva yıkan kadın olarak gösterilirken, çalışmak isteyen kadınlar ise filmin sonunda eve döndürülerek hataları kabul ettiriliyordu. $\mathrm{Bu}$ durum, sinemada kadın imgesinin temsil değil bir inşa süreci olduğunu göstermektedir.

Hollywood sinemasında erkek yönetmenlerin bakış açısı, karakterleri konumlandırma biçimi ve çekim teknikleri gibi unsurlar izleyicinin erkek ve kadın karakterlere yönelik algısını belirlemektedir. Bu durumu Ryan ve Kellner (2010, s. 221) şu şekilde açıklamaktadır;

"Olay örgüsü ve diyaloglar genellikle kamusal değil, kişisel sorunlar etrafinda döner; olaylarn gectiği mekânlar

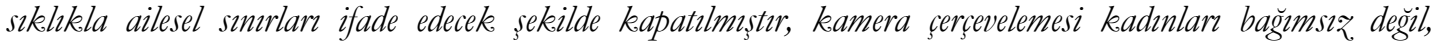
ilişkilere bağıml olarak resmeder; kullanilan güzel oyuncularla sik. sik. bassvurulan yakin çekimler kadmm erkek arzularmin nesnesi olduğu anlamm destekler...."

Hollywood sinemasinda yapılan aile filmlerinde kadınlar genellikle sevgi besleyen anneler olarak, erkekler ise eve bağlanması için çaba sarf edilen babalar olarak gösterilmektedir. Amerika'nın muhafazakâr yapısında önemli bir yeri olan aile kurumu, Hollywood filmlerinde bu yapının devamını sağlayan en önemli unsur olarak sunulmaktadır. Hollywood'un erken dönemlerinde film türlerinin oluşmaya başlamasının temel saiki olarak görülen tematik uylaşımlar, aile kurumunu önemseyen bir yapıya sahiptir. Bu durumu Abisel şu cümlelerle açılamaktadır (1995, s. 36); 


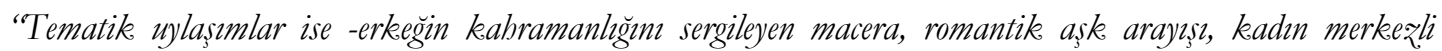
melodram, kurtulusu sağlayan şiddet, irklara ve suça yönelik stereotipleştirme vb.- gerceklike etkisini, toplumsal değerlere ve kurumlara, bunlarn doğal ya da değismeyen bir dünyanin kendinden menkul açı. nitelikleri olarak. gösterecek biçimde bağlayarak ideolojizi güclendirirler. Bu köktenci görïs, uylassimlarm seyirciyi, toplumsal düzenin temel önermelerini kabule ve bunlarm usdışliğm ve adaletsizliğini yok saymaya alsstrrdiğm iddia etmektedir. Bunlar, savaș, suc gibi toplumsal yapiya iliskin meseleleri kişisel yaşam öyküllerine yerleștirerek, var olan düzeni "ablaki" ve "iyi" olarak gösterilebilmektedir."

Hollywood'da toplumsal kurumlar ve değerlerle birlikte ortaya çıkan stereotipleștirme kadın ve aile ilişkisi üzerinden somutlaşmaktadır. Kadınların stereotipler halinde gösterilmesi, anne olarak ev içi yaşamda iş yapması ile başlamaktadır. Böylelikle hem Amerika'nın muhafazakâr aile yaşamı ile mevcut toplumsal yapısı korunmakta hem de kadınlara kimliklerinin mekânı olarak bulunmaları gereken yer gösterilmektedir.

Klasik anlatı sinemasindan beslenen Hollywood sineması, yapısalc1 dilbilimden esinlenerek karakterleri olay örgüsü içinde belirli biçimsel yapılardan geçirerek sonuca ulaştırmaktadır. Propp’un 31 işlevinde de bulunan bu şablonda karakterler önce evden çikmakta, masalın ya da filmin sonunda ise yine eve dönmeleri gerekmektedir. Burada evden çıkma metaforuyla bulunulan güvenli bölgeden ayrilma ve tehlikelerle dolu bir dünyaya yolculuk etme ifade edilmektedir. Eve dönme ise tıpkı ana rahmine dönme gibi huzuru temsil etmektedir. Aileyi temsil eden ev ile tehlikeyi barındıran dışarısı bu anlamda filmlerde kadın ve erkek kimliği üzerinden de anlaş1ır hale getirilmektedir.

"Aile bir mabremiyet sı̆ğnağıdrr, kendi üzerine kapanan bir dünyadrr, dişardan gelecek biçbir tecavï̈ü kabul etmeyen bir yüz yüze yakınlık mekânuder. Dışarısı ailevi yakunlğgn bozulması olarak tanmmlanur ve

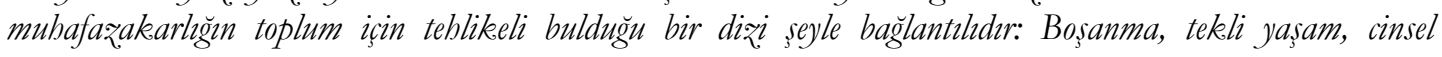
bastallklar, kürtaj, kadinlarn çalısması vb.....” (Ryan ve Kellner, 2010, s. 255)

Filmlerde kadının iş yaşamı içinde yer alması ailede istenmeyen bir durum olarak gösterilirken, mekânsal olarak da dışarıyı ve tehlikeleri temsil etmektedir. Kadının iş yaşamı içinde yer alması aynı zamanda özgürlügünü ele geçirmesi ve daha kolay boşanabilmesini beraberinde getirmektedir. Böylece iş yaşamı kadının hayatına yön vermesinde güçlü bir metafor haline dönüşmektedir.

Feminizmin 1960'lı yıllarda kadının sinemada kendi cinselliğini sahiplenmeye teşvik edilmesinin neticesinde kadın cinselliği baskılanmayarak filmlerde gösterilmeye başlanmıştır. Bu durum sinemada kadınlara tecavüz sahnelerinin sıkça yer aldığı filmlerin sahnelenmesine neden olmuştur. Bu filmlerde kadın, artık kötü kadın olarak değil, cinselliği arzulayan kadın olarak tasvir edilmekte ve kadının cinselliğe olan bu arzusu ceza olarak tecavüz sahneleriyle meşrulaştırllyordu. $70^{\prime}$ li ylllarda feminist film eleştirisine bir başka tepki olarak ahbap (erkekleri konu alan filmler) filmleri yapılmış ve kadınların perdeden uzaklaştırılmasına neden olmuştur (Özden, 2004, s. 195-197). Sonuç olarak kadınların sinemada kendi istekleri doğrultusunda bir özgürlük anlayışına çok kolay sahip olamayacağı anlaşılmışıır.

\section{Liberal Feminizm ve 'Süper Kadın' Kimliği}

Kapitalizmden önce de varllğını sürdüren patriyarkal yapılar, kapitalizm ile birlikte yeni görünümlere kavuşmuştur. Bu yeni görünüm kamusal ve özel alanlarda, fabrika ve işyerlerinde ve burjwa aile içerisinde kadinn erkeğe tabi olmasını sağlamıştır (Kellner, 1998, s. 251). Zaten ilk feminist hareketin başlamasında da kadının toplumda varlığını gösterememesi yatmaktadır. 18. yüzyılda Mary Woolstonecraft tarafindan ateşlenen feminist hareket, kadının bir vatandaş kimliğine sahip olma isteğinden yola çıkarak başlamıştır. Woolstonecraft, kadın bedeninin, güzellik ile temsil edilmesini eleştirmekte, kadının güzelliğe odaklanmak yerine akli yeteneklerinin geliştirilmesi gerektiği üzerinde durmaktadır (2007, s. 35). Woolstonecraft "Vindication of the Rights of Women" (1792) adlı eserinde Rousseau'nun Emile kitabını eleştirmektedir. Bir çocuğun yetiştirilme biçimlerini ele alan kitabın "Kadın Terbiyesi" adlı bölümünde, bir kızın güzel

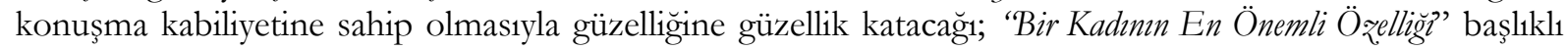
bölümünde ise çocukluktan itibaren itaate alıştırlmasıyla büyüdüğünde de bir erkeğin kararlarına itaat edeceği ifade edilmektedir (Rousseau, 2018, s. 232-234).

Woolstonecraft'ın Emile romanına yönelik eleştirisinin özünde kadının ev ile ilişkilendirilmesi ve zengin bir erkeğin göstereni olarak kullanılması yatmaktadır. Bu kapsamda Woolstonecraft, toplumda kadınla ilişkili bir reform yapmak için öncelikle kadının toplumsal konumunun dönüşümünün gerekliliğini 
ileri sürmektedir. Çünkü kadının kamusal yaşamda kendi düşüncelerini özgürce ifade etmesinin yolu ev yaşamından kamusala açılmasından geçmektedir.

Erken dönem liberalleri kadının eşit oy ve mülkiyet hakkeına sahip olması için çalışmalarına karşın, günümüz liberalleri eşit ücret ve istihdam konularına yönelmişlerdir (Steeves, 1994, s. 114). Bu alanda yapılan liberal feminist çalışmalar, kadınların toplumsal yaşamda cinsiyetçi olmayan tarzda temsil edilmesi için iki yol önermektedir: kadınların toplumda erkeklerle eşit biçimde yer almaları ve erkek egemen alanlarda kendi varlıklarını kanıtlamalarıdır. Bu önerilerin medya alanında gerçekleştirilebilmesi için gazetecilik eğitimi verilen yerlerde cinsiyetçi olmayan profesyonel bir mesleğin öğretilmesi gerektiği üzerinde durulmaktadır. Ancak liberal medya çalışmalarının sonucu olarak medyada kadın temsili, güçlü, ayakları üzerinde duran ve güzel kadın imgesine sahip süper kadn olarak sunulmuştur (Van Zoonen, 2002, s. 474). Liberal feminizm, kadının toplumsal yaşamda erkek ile beraber varlığını kanıtlamasını isterken, başarılı ve güzel kadın temsillerinin medyada sıkça kullanılmasına yol açmaktadır. Özellikle liberal feminizmin çıkış noktası olan kadının ev yaşamından kurtarılması fikri, kadını iş yaşamında kurgularken onun cinsel bir obje olarak görülmesinin önüne geçememektedir. Liberal feminizm, kadını ve erkeği eşitleyerek kadını sadece yurttaş olarak görme eğilimindedir.

Medya ana akım içerisinde aile kurumuna önem atfederek toplumsal yapının devamlılığını sağlama almaya çalısmaktadır. Bu anlamda medya, stereotipleri kullanarak kadın, erkek ve çocuklara uygun rol modellerin toplumsal yapıda sürdürülmesine hizmet etmektedir. Kadın erdemi olarak görülen cinsel pasiflik, medyada kadın karakterlerle temsil edilerek iffetli kadın imgesinin oluşmasına ve devamına katkı sağlamaktadır (Kim, 2008, s. 400).

Süper kadın, sadece iş yaşamında değili ev yaşamında da başarılı olan, aynı zamanda ideal bir bedene sahip kadını tanımlamaktadır. Toplum tarafindan takdir toplamak isteyen süper kadınlar, her şeyi yapmaya ve yaptıkları işlerde başarılı olmaya çalışmaktadırlar (Everett ve Martino, 2014, s. 145). Feminizmin başlangıç yıllarından itibaren kadın kimliğinin mekânsal olarak evle ilişkili şekilde tanımlanmasına karşı verilen mücadele kadın, ev ve iş mekânları arasında mükemmel kadına evrilmiştir. Aslında bu durum, liberal feministlerin taleplerine ticari kültürün vermiş olduğu bir cevap olarak değerlendirilmektedir (Van Zoonen, 2002, s. 475). Bu nokta, kadının ev ile sınırlandırılmış yaşamından kurtulma ve kamusal alanı ifade eden iş yaşam alanlarına girme arzusu ile ilişkili olarak kurulmuştur. Bunun yanında kurgulanan süper kadının güzel beden ölçülerine sahip olması arzu edilmektedir. Bu şekilde bir tarafta ev ve ev içi her türlü iş kadının sorumluluğunda görülürken diğer taraftan iş yaşamında da başarılı kadın imgesi inşa edilmeye çalışlmaktadır. Bu anlamda süper kadın imgesinin içinde başarılı bir eş, fedakâr bir anne, başarılı bir iş kadını ve bedenine dikkat eden çekici kadın kimlikleri bütünleşik olarak yer almaktadır. Aynı anda dört kadın kimliğini içeren bu kimlik, liberal feminizmin medyadan beklentilerine verilen bir cevap olarak okunmaktadır. Çünkü kadın medyada bu dört kadın kimliği ile ilişkili olarak temsil edilmektedir. 1960’ların feminist hareketinin bir sonucu olarak ortaya çıkan süper kadın kimliği, kadının farklı mekânsal alanlarda elde ettiği kimliklerin alaşımı olarak görülmektedir. Süper kadın, evde, işte ya da farklı alanlarda edinilen farklı kimliklere gönderme yapmaktadır.

Hollywood sinemasında 60'lı yıllarda azınlık olan feministler, giyim kuşamlarında kadınsı tavırlardan uzak durmaya çaba sarf etmişlerdir. 70'li yıllarda kadın giyiminde belirginleşen androjen eğilim, kadının erkeksi bir dış görünüşe sahip olmasını ifade etmektedir. Sütyen takmayan, pantolon giyen ve kısa saçlı (Davis, 1997, s. 46) bu kadın kimliği de bir süre sonra feminist kadınların erkeklere benzemesiyle ilişkili olarak uzak durulması gereken bir dış görünüş olarak vazgeçilmiştir. Mulvey, sinemada kadının teşhirci bir biçimde bakılması gereken olarak kodlandığını ileri sürmektedir. Yani bu kadın, kendi bedenini teşhir ederken aslında kendisine bakılmasına istekli olarak gösterilmektedir. Bu anlamda erkek hazzının kurucu öznesi haline gelen kadın, sinemadaki varlığını bu şekilde kanıtlamaktadır.

Süper kadın idealinin oluşmasında erkekesilike, mülkemmeliyețilike ve beden imajı olarak üç faktör yer almaktadır (Martino ve Lauriano, 2013, s. 168). Erkeksilik, kadının erkeklerin başarılı olduğu alanlarda kendisini kanıtlamaya çalışması olarak değerlendirilmektedir. Kadının iş yaşamı içinde yer alması, ev içi alanda yapmış olduğu işlere artı bir iş yükünü ifade etmektedir. Erkeklerin sadece işle ilgili alanlarda bir zorunluluğa sahip olmasına karşın, kadınlar hem ev hem de iş alanının zorunluluklarını yüklenmektedir. Bu da kadınları mükemmeliyetçiliğe erişmek için daha fazla çaba sarf etmeye zorlamaktadır. Ancak mükemmellik dürtüsü kadının yetişemediği alanlar için yetersizlik duymasına yol açmaktadır (Martino ve Lauriano, 2013, s. 169). Bu nedenle de ev içi alandan uzaklaşan kadın, buradaki zorunluluklarını ücret karşıllğı yaptırma yoluna gitmektedir. Böylelikle, ev işleri ve çocuk bakımı gibi ev içi zorunluluklarını ücret 
dahilinde yaptıran süper kadının iş yaşamında başarıya giden yol açılmaktadır. Aslında "ber şeye sabip olan ve her seyi yapabilen postfeminist süper kadin gercek. hayatta yok. Kadmlarn karş karşıy a kaldĭğ sistemik baskılar nedeniyle - cocuk bakem ve günlük ev işlerini bitirmeye yardm edebilecek varlkkl kadinlar bile - hepsine sahip olmalar tam anlamuyla imkânsızder" (Haralovich ve L. Press, 2010, s. 226).

Bu süreçte, süper kadın kimliğinin vazgeçilmez bir parçasını dış görünüş oluşturmaktadır. Kadının dış görünümü, onun cinsel çekiciliği ile ilişkili olarak değerlendirilmektedir. Bedenine dikkat eden, modaya uygun giyinen kadın, kapitalist ideolojinin kadını görmek istediği bakışın bir ürünüdür. Liberal feministler medyada kadının temsilinde stereotipleşmeye karşı çıkarken kadının sınırlı roller içerisinde gösterilmesine tepki göstermektedir. Bu stereotiplerden bazıları da kadınların anne, eş, sekreter, hemşire gibi rollerde; her zaman güzel ve çekici olarak gösterilmeleridir (Van Zoonen, 2002, s. 473). Bu anlamda liberal feministlerin kadınların farklı rollerde gösterilme talepleri Hollywood tarafindan karşılık bulsa da çekici kadın imgesi hiç değişmeden kadın kimliğine eklemlenmiştir.

\section{Çalışmanın Amacı}

Yapılan birçok akademik çalışma kimlik ve mekân arasında güçlü bir ilişki olduğunu göstermektedir. Bu noktada toplumun önemli unsurlarından biri olan kadın kimliği ile mekân arasında da ayrilmaz bir ilişkinin varlı̆̆ kesindir. Kadın kimliği, bir yandan parçası olduğu mekânları biçimlendirirken diğer yandan da bu mekânlara bağlı olarak biçimlenmektedir. Kadın kimliği ile mekân arasındaki bu girift ilişki, kadın kimliğinin tanımlanmasına neden olarak kadının nerede ve nasıl davranması gerektiğine ilişkin toplumsal roller ve kurallar silsilesini ortaya çıkarmaktadır. Buradan yola çıkan bu çalışmanın temel amacı da kadın kimliği ve mekân arasındaki ilişkiyi Sex and the City 2 filmi örneğinde inceleyerek somut göstergeler üzerinden analiz etmektir. Film, sadece ismiyle bile bu ilişkiyi analiz etmeye oldukça elverişli bir örnek sunmaktadır. Cinsiyet anlamına da gelen 'sex' kelimesi ile mekânı temsil eden şehir, metropol anlamındaki 'city' kelimeleri kadın kimliği ve mekân arasındaki bağı kurmaya yetmektedir.

Çalışma, kadın kimliğinin tanımlanması ve mekânla olan ilişkisinin ortaya konması noktasında filmin dört ana karakteri üzerinden gitmektedir. Filmin bu dört kadın karakteri, New York’ta yaşayan Amerikan modern kadın kimliğini temsil etmektedir. Genç, güzel, bakımlı hem evde hem de işte başarılı olan bu kadınlar süper kadın kimliğini temsil etmektedir. Ancak kadınların bu kimliği mekâna bağlı olarak ortaya çıkan bir kimliktir. Nitekim filmin New York'ta başlayıp Abu Dabi'ye uzanan ve yeniden New York'a dönüşle birlikte sona eren yolculuğu mekânlarla birlikte kadınların kimliklerinin de dönüşüm yolculuğudur. Karakterlerin süper kadın kimliğiyle çıktıkları bu yolculuk, Castells’in meşrulaştırıcı kimliğiyle sona ermekte, toplumsal yapının istediği kimliğe evrilmektedir. Bu durum filmde mizansen, bakış açısı, konumlandırma gibi farklı sinematografik öğelerin kullanımıyla da desteklenmektedir.

\section{Filmin Konusu}

Dört kadın karakteri merkeze alan Sex and the City 2, Michael Patrick King tarafindan yönetilen ve 2010 tarihinde gösterime giren Amerikan yapımı romantik komedi filmidir. Film, Candace Bushnell'in aynı isimli romanından ilk olarak 1998 yllında Michael Patrick King tarafindan televizyon dizisi olarak uyarlanmıştır. 17 ülkede izleyicilerin büyük bir beğenisini toplayan diziyi King, 2008 yllında sinema filmi olarak izleyiciyle buluşturmuştur. Sex and the City 2 ise aşk, evlilik, arkadaşlık, iş, cinsellik gibi birçok konuyu dört kadının dostlukları üzerinden ve kadın bakış açısıyla ele alan filmin devam filmi olarak 2010 yılında gösterime girmiştir. Başrollerini Sarah Jessica Parker, Kim Cattrall, Kristin Davis ve Cynthia Nixon'un paylaştığı filmin konusu "kafası karışık, güçlü, hüzünlü kent kadınlarının zorlu serüvenlerinin ikinci kısmı" (beyazperde.com) olarak tanımlanmaktadır.

Filmde Carrie, Samantha, Miranda ve Charlotte çok eski dört arkadaştır. New York'ta yaşayan güçlü ve kariyer sahibi bu dört arkadaş Abu Dabi'ye bir seyahate çıkarlar. Ancak bu seyahat onları bambaşka coğrafyalar, bu coğrafyaların farklı toplumsal yaşamları ve kurallarıyla tanıştırır. Yine burada, kadınların etrafında dönmeyen, kadının yok sayıldığ bir kültürle karşı karşıya kalı; bu coğrafyada yaşayan hemcinslerinin kaderlerine tanıklık ederler. Umduklarından çok farklı sonuçlarla biten bu seyahat, karakterlerinin aslında kim oldukları ve gerçekte ne istediklerini sorgulamalarını sağlar. Filmde Sarah Jessica Parker, Carrie karakterini canlandırmaktadır. Filmin anlatıcısı konumundaki bu karakter, evli ve kariyer sahibi bir yazar olarak karşımıza çıkmaktadır. Başlangıçta monoton bir ilişki ve geleneksel bir evliliğe karşı çıkan Carrie, filmin sonunda mutluluğun bu tür bir evlilikte olduğuna karar vermektedir. Kim Cattrall'ın canlandırdığı Samantha karakteri ise cinselliğin ve tüketim kültürünün kadın bedeni üzerinden sunumuyla ön plan çımaktadır. Kapitalizmin kadın bedenine olan düşkünlüğ̈nün başarılı bir yansıması 
olan Samantha karakteri, özellikle doğu toplumları için sıra dışı bir kadın kimliğini temsil etmektedir. Filmde Miranda karakteri ise Cynthia Nixon tarafından canlandırılmaktadır. İş yaşamında başarılı bir kariyeri olan Miranda, bu kariyerin bedelini anne ve eş olarak kaybettikleriyle ödemektedir. İyi bir avukat olmasına rağmen, kadın olduğu için iş yaşamında takdir edilmeyen hatta duymazdan gelinen Miranda, özel yaşamında ise aldatılmayı kabullenmiş bir eş; ihtiyacı olduğu zamanlarda çocuğunun yanında olamayan bir annedir. Charlotte karakteri ise Kristin Davis tarafından canlandırlmaktadır. Mutlu ve iki çocuklu bir ev kadınını canlandıran Charlotte, gündelik ev işleri ve çocukların stresinden arkadaşlarına sığınarak kurtulmaktadır. Filmde başka kadınları evliliğine tehdit olarak gören ve bunu sıkınt yapan sıradan kadın stereotipi, evliliği ve çocukları dışında başka bir meşgalesi olmayan Charlotte karakterinde vücut bulmuştur.

Film, bu dört kadının görünürde New York'tan Abu Dabi'ye olan, ama aslında içlerine doğru yaptıkları seyahati konu almaktadır. Filmde Abu Dabi seyahatleri her ne kadar hayal kırıklığı ile sonuçlansa da içsel yolculukları mutlu sonla bitmektedir.

\section{Yöntem}

Sinemada olay örgüsü ve karakterler yönetmenin bakış açısına göre şekillenmektedir. Yönetmenin bakış açısı ise izleyicinin olaylara ve karakterlere yönelik algısını etkilemektedir. Hollywood sinemasında baskın olan eril bakış açısı, kadınların bu filmlerde pasif ve güzel olarak temsil edilmesine neden olmaktadır. Kadınlara yönelik bu algının oluşmasında önemli bir başka etken ise olay örgüsü içinde onların temsil edildikleri mekânsal unsurlardır.

Buradan hareketle çalışma, filmdeki kadın kimliği ve mekân arasındaki ilişkiyi liberal feminist medya çalışmaları temelinde ele almaktadır. Bu çalışmalar içerisinde yer alan 'süper kadın' kimliği ise film karakterleri üzerine niteliksel analiz yapılmasına imkân vermiştir. Niteliksel analiz, ampirik olmayan ve anlama odaklanan bir analiz türüdür. Bu analiz türünde yazılı metinlerin yanında film, film sahnesi ya da reklam gibi görsel işitsel ürünlerdeki anlam ya da anlamsal yap1 incelenmektedir. İnceleme yapilırken, araştırılan konu önce parçalara bölünerek anlamlandırlır ve sonrasında parçalar bir araya getirilerek anlamlı sonuçlar ortaya çıkarılmaktadır (Erdoğan, 2012, s. 273). Bu çalışmada, filmdeki kadın karakterler incelenirken ‘süper kadın' kimliği üzerinden kadın-kimlik ve mekân ilişkilerine bakılmıştır. Buna göre, New York ve Abu Dabi şehirleri kadın kimliğini belirleyen temel mekânlar olarak kabul edilmiş ve iki şehir arasındaki kadın kimlikleri ve davranış şekilleri incelenmiştir. Ayrıca "süper kadını" oluşturan anne, iş kadını ve güzel kadın imgelerinin filmdeki izdüşümlerini bu şehirlerdeki ev içi mekânlar, iş yaşamına ait mekânlar ve alışveriş mekânları oluşturmaktadır. Bu mekânlar ise çalışmada incelenecek alt kategoriler olarak belirlenmiştir.

\section{Bulgular}

Çalışmaya ait bulgular temel mekânlar olarak New York ve Abu Dabi şehirleri ile bu şehirlere ait ev içi mekânlar, iş yaşamına ait mekânlar ve alışveriş mekânları olmak üzere belirlenen kategoriler altında değerlendirilmiştir. Filmde genel olarak iki şehrin, özelde de alt kategorilerin toplumsal yaşamdaki kadın kimliğinin oluşumuna etkileri incelenmiştir.

\section{New York / Ev İçi Mekânlarda Kadın Kimliği}

Genel olarak değerlendirildiğinde, New York şehri özgür ve güçlü kadın kimliğinin en önemli mekânlarından birini temsil etmektedir. Gücünü 'özgürlükler ülkesi' olarak bilinen Amerika Birleşik Devletleri'nden alan şehir, kadınların hayatlarını istedikleri gibi ve hiç kimseye hesap vermeden yaşayabilecekleri bir mekân olarak sunulmaktadır. Nitekim film karakterlerinin New York'ta geçen yaşamlarında da kadınlar özgür ve güçlü kimliklere sahip bireyler olarak sunulmaktadır.

New York'ta kadın kimliklerinin sunulduğu önemli mekânlardan biri ev içi mekânlardır. Ev, aile birliğinin temelini oluşturan mekânsal varoluş alanıdır. Ev ailedir, huzurdur, güvendir, birlikteliktir. Gerek medyada gerekse de sinemada kadın kimliğiyle özdeşleşmiş bir mekândır. Evin kadın kimliğiyle olan ilişkisi sadece mekânsal bir ilişki değil, aynı zamanda tarihsel, kültürel ve küresel bir ilişkidir. Geçmişten günümüze, dünyanın hemen her yerinde, kadının yeri olarak ev gösterilmektedir. Kadın evi çekip çeviren; aileyi bir arada tutan kişidir. Bu mekâna duygusal bir anlam yükleyerek 'yuva'ya dönüştüren kişidir. $\mathrm{Bu}$ mekânda kadın, bazen 'ev kadını', bazen 'eş', bazen de 'anne' kimliğiyle varoluş mücadelesi vermektedir.

Filmde ev içi mekânlar Carrie, Miranda ve Charlotte karakterleriyle kurgulanmıştır. Bu üç karakterin evli olması ev içi mekânlarda kadın kimliğinin inşa edilmesinde güçlü bir unsur olarak kullanılmıştır. Kadın 
kimliğinin en önemli belirleyeni, hatta kadın kimliğiyle özdeş kabul edilen ev, film karakterlerinin kimlikleriyle doğrudan ilişkili bir mekân olarak sunulmaktadır.

Filmin ana karakterlerinden Carrie için ev, kocasıyla birlikte yeni taşındığı ve mutlu bir hayatı paylaşacağı bir mekânı temsil etmektedir. Bu yeni mekânın eksiklerinin belirlenmesi, satın alınması ve dekorasyonunun yapılması Carrie'nin sorumluluğundadır. Bu durum, "yuvayı dişi kuş yapar” gibi oldukça kalıplaşmış ve mekânı cinsiyetleştiren bir söylemin filmde yeniden üretilmesi anlamına gelmektedir. Aile birlikteliğine ve yeni başlangıçlara işaret eden bu mekân, aynı zamanda karakterin kimliğinin de bir yansımasını sunmaktadır. Buna göre Carrie, ev içi mekânı şekillendiren güçlü ve özgür bir kadındır. Ancak onun için ev, geleneksel bir evliliğin vuku bulduğu sıradan bir yer değil, iki aşığın birlikte keyifli zamanlar geçireceği bir mekândır. Carrie'nin hayata ve evliliğe bakış açısını anlatan 'ev', aynı zamanda onun geleneksele karşı olan duruşunu da simgelemektedir. Geleneksel ve mutlu bir evlilikte birliktelik, huzur, güven, gelecek anlamına gelen ev; mutsuz bir evlilikte içine kadının acıları ve gözyaşlarını hapsettiği bir 1stırap yeri olarak dört duvara da dönüşebilmektedir. Böylesi bir durumda ev, kaçılması ve kaçınılması mümkün olmayan bir zorunluluk halinin adresi olmaktadır. Oysaki güçlü bir kadın kimliğinin temsilini sunan karakter, kendi ayakları üstünde duran, geleneksel değerlerden oldukça uzak bir kadındır. Onun geleneksele olan karşllığ ve özgürlüğe olan düşkünlüğü yine 'ev' üzerinden sunulmaktadır. Karakterin evlenmeden önce yalnız yaşadığı dairesi, Carrie karakterinin gerektiğinde kocasından ve evliliğinden kaçtı̆̆ bir sığınağı temsil etmektedir. Bu mekân Carrie'nin bireysel olarak varoluşunun bir göstergesidir. O, geleneksel evliliklerde olduğu gibi iki farklı kişinin aynı kişiye dönüşmesini değil; iki kişinin iki farklı birey olarak var olmasını isteyen bir karakterdir. Çalışan, kendi yaşamını kendisi kurabilen, başarılı ve güçlü bir kadındır. Evlilik onun kimliğinin sadece küçük bir parçasıdır; onu var eden değil tamamlayan bir parçası.

Mekânsal anlamda evle özdeş bir şekilde kadın kimliğini tamamlayan önemli alanlardan biri de mutfak ve mutfak işleridir. Carrie karakterinin evle bağlantılı bu mekânda hiç görülmemesi ya da yemek gibi kadının evdeki kimliğinin temel belirleyicilerinden olan işleri yapmaması; dahası satın alması da süper kadın kimliğinin önemli göstergelerindendir. Bu anlamda Marksist feministlerin ev işlerinin ücret dahilinde yapılması fikrinin modern kadının yaşamında yer bulduğu açıcça görülmektedir. Süper kadın kimliği ile ilişkilendirildiğinde, iş yaşamının gündelik hayatın büyük bir kısmını işgal etmesiyle beraber süper kadınlar, eve ait olan işleri ücretli olarak yaptırmakta ya da eşlerle paylaşmaktadır.

Filmin üst metninde Carrie karakteri süper kadın kimliğiyle sunulmasına rağmen, alt metindeki bazı göstergeler ev içinde ataerkil bir düzenin devamlılı̆̆ına işaret etmektedir. Carrie'nin kocası Big'in kanepeye ayaklarını uzatarak televizyon izlemesi, Carrie'nin ise çok da rahat gözükmeyen tekli bir koltukta ona eşlik etmesi; ya da Big'in yatak odasında televizyon izleyerek uyumak istemesi ve bunun için bir televizyon satın alması Carrie'nin tüm karşı çıkmalanına rağmen evde erkeğin sözünün geçtiğinin kanıtlarıdır.

Bir başka ev içi sahne de ise Big'in şu sözleri duyulur; "Benden ne istiyorsun, bir gömlek giydim galaya gittim simdi de yatağa uzamp biraz. televiagyon seyrettiğim için bana vaaz veriyorsun. Yani senin derdin ne..."

Bu diyalogla Carrie, isteklerinin ardı arkası kesilmeyen kadın stereotipiyle sunulmaktadır. Carrie'nin güçlü kadın karakteri duygusal anlamda Big'e olan bağlllığıyla da seyirciyi hayal kırıklığına uğratmaktadır. Aslında kadın bu filmle de gösterildiği üzere hiçbir şekilde erkek kimliğinden ayrı bir kimliğe sahip olamamaktadır (Douglass ve Kellner, 2010, s. 77).

Carrie'nin evliliğe olan bakış açısı sıradan evlilik yaşamının dışında farklı bir yapıya sahiptir. Evliliğin temeli olarak kabul edilen çocuk ve göstergesi olan yüzük Carrie için sıradanlaşmanın ifadeleridir. Bu nedenle Carrie her ikisine de karşı çıkmaktadır. Ancak Abu Dabi seyahati onun bu konudaki fikirlerini değiştirmesine sebep olacaktır. Evliliğin tıpkı bir gelinlik gibi olduğunu, bu gelinliğin kendine göre ayarlanması gerektiğini anlayan Carrie filmin sonunda, evliliği Abu Dabi’deki peçeli kadınlar gibi düşünmeye başladığını itiraf ederek geleneğin alanı içerisine girmektedir.

Miranda karakterinin ev içi mekândaki kimliği mutfak sahnesiyle tanımlanmaktadır. Sabah kahvaltısına şahit olunan karakterin 'eş', 'anne' ve 'çalışan kadın' kimlikleri sunulmaktadır. Bu üç kimlik, evinde yardımcısı olmasına rağmen Miranda'nın bütün işlere yetişmesine engel olmaktadır. Karakterin kendisini "Ben avukatım, bu kimlï̈imin bir pargası" şeklinde tanımlaması karakterin kariyerini öncelediğini göstermektedir. Nitekim karakterin filmin anlatı yapısı içinde eş ya da anne kimliklerinden ziyade işiyle gündeme gelmesi de bunun önemli bir göstergesidir. Kadının eş kimliği ve anne kimliği geleneksel yapının benimsediği meşrulaştırıcı kimlik unsurlarıdır. Miranda'nın sahip olduğu avukat kimliği ise, çalışma 
mekânlarında var olan ancak susturulan ve sesine tahammül edilemeyen bir kadın kimliği olarak gösterilmektedir.

Filmde ev içi mekânda görülen bir diğer karakter de Charlotte karakteridir. İki küçük kızı olan Charlotte, dağınık bir mutfak tezgâhında büyük kızının okulu için kek hazırlarken görülmektedir. Bu mekân ve bu mekâna bağlı olarak ortaya çıkan iş Charlotte'ın geleneksel ev kadını kimliğini ortaya koymaktadır. Karakterin çalışı̆ğ dağınık mutfak aslında kimliğinin parçalanmışlığına gönderme yapmaktadır. Kızlarının küçük olması ve sürekli ağlamaları onun anne kimliğini tam olarak kabul edememesine neden olmaktadır. Ayrıca çocuklarının bakımı için bir dadıdan yardım alıyor olması da kendi başına annelik kimliğini yerine getiremediğinin göstergesidir. Charlotte bir yandan mükemmel bir anne olmaya çalısırken diğer yandan da kendi bağımsız kadın kimliğini korumaya çalışmaktadır. Süper Kadın kimliği ile bağ kurulduğunda Charlotte, güzel bir evde yaşayan, iki çocuğa ve onların bakımını üstlenen bir dadıya sahip olan, yaşına rağmen güzelliğinden ve giyiminden taviz vermeyen kadın ile temsil edilmektedir.

\section{New York / İş Yaşamına Ait Mekânlarda ‘Çalışan Kadın’ Kimliği}

Filmde çalışan kadın kimliği Carrie, Miranda ve Samantha karakterleri üzerinden sunulmaktadır. Carrie ünlü moda dergisi Vogue'da köşe yazarlı̆ğ yapmaktadır. Miranda bir avukattır. Samantha ise halkla ilişskiler uzmanı olarak çalışmaktadır. Bununla birlikte mekânsal olarak iş yaşamında sunulan tek karakter Miranda'dir.

Filmde Miranda erkek egemen bir toplantı masasında görülmektedir. Erkek bir patron tarafindan başkanlık edilen toplantıda Miranda tek kadın çalışan olarak dikkat çekmektedir. Toplantıda patronu tarafından el işaretiyle susturulan ve konuşmasına izin verilmeyen Miranda'nın elindeki başarılı proje de alınarak erkek bir çalışana verilmek istenmektedir. Bunun üzerine Miranda'nın patronunun konuşmasını aynı el hareketi ile kestiği görülmektedir. Bu durumdan rahatsız olan patronu; "Bana özel olarak söylemek istediğin bir șey var mı?" diye sormaktadır. Miranda, "Öz̧el olarak söylemem gerekir mi bilmiyorum” sözlerinin ardında, sabah işe gelirken çalıştığı için katılamayacağını söylediğgi, oğlunun bilim yarışında gösterilmektedir. Böylelikle seyirciye Miranda'nın işinden istifa ettiği anlatılmaktadır. Filmde mekânsal olarak toplantı odası ile temsil edilen iş yaşamı ve bu alanda kadınların bastırılması, susturulması ve yok sayılması filmin ilerleyen sahnesinde, Carrie’nin köşe yazısında, ağzına bant yapıştırılmış bir kadın çizimiyle yansımaktadır.

Ataerkil bir toplumda kadının sesine bile tahammül edilememe durumu filmde ikinci kez de karakterlerin Abu Dabi seyahati esnasında görülmektedir. Önemli bir dergi Carrie'nin ağzına bant yapıştırılmış karikatürünü kullanarak 'Sessizlik Yemini”' başlıklı bir yazı yayınlamaktadır. Yazıda "Bana göre yetenekli Bradshaws evlilik, hayatmn karmaşılehğm öæümseyene kadar biri ona sessiz̨lik yemini etmeyi tavsiye etse iyi olur" cümlesi yer almaktadır.

Böylelikle, kadınların iş yaşamında başarılı olmasına karşın erkek egemen yapı tarafından dışarıda bırakılmak istenmesi filmde iki şekilde yansıtılmaktadır. Kadınlar çalışma hayatına girmesiyle her ne kadar özel alandan kamusal alana açılsalar da kadın kimliğinin bu mekânda istenmediği açıkça görülmektedir. Kamusal ataerkillik olarak tanımlanan bu durum, kadınların kamusal alanda var olmasına rağmen ezilmelerine işaret etmektedir (Walby'den Akt. Kandiyoti, 2011, s. 164). Toplumsalın kurgusal olana bir yansıması olarak okunabilecek bu duruma film karakterlerinden Miranda şu sözlerle dikkat çekmektedir; “......patronumun hoşuna gitmeyen ses tonum değildi. Bir sesimin olmasindan hoșlanmad. Amerikalı erkekler güçlü kadinlardan rahatsı olmuyormus gibi yapiyor ama çoğu peçenin altundan patates kizartması yememizi tercih eder." Böylece hem görsel hem de sözel olarak Amerikalı süper kadınların da tıpkı Abu Dabi'li kadınlar gibi eril şiddete maruz kaldıkları seyirciye aktarılmış olmaktadır.

Filmde iş yaşamıyla ilgili bir diğer sahnede yine Miranda görülmektedir. Bu sefer yeni iş arkadaşlarıyla yeni işini kutlamaktadır. Miranda'nın yeni iş yerinin adı 'Global Feminist' isimli bir şirkettir. Hayatından memnun ve mutlu görünen Miranda, artık sesine değer verilen bir yerde çalışmaktan duyduğu memnuniyeti "Gururla bildirmek isterim ki, Global Feminist șirketi ile yaptuğrm anlaşma beklentilerimin cok ötesinde yarar sağlad’" sözleriyle seyirciye aktarmaktadır.

\section{New York / Alı̧veriş Mekânlarında "Tüketici Kadın” Kimliği}

Filmde tüketici kadın kimliğinin konumlandığı en önemli mekânlardan biri New York şehridir. New York alışverişin, güzel giyinmenin, bakımlı olmanın mekânı olarak sunulmaktadır. Daha filmin başında, karakterleri bakımlı ve bakımsız halleriyle gördügümüz yer de yine New York sokaklarıdır. Burada ilk olarak Carrie, spor kıyafetler içinde taksi durdurmaya çalışırken görülmektedir. Ancak böylesi bakımsız bir kadın için hiçbir araç durmamaktadır. Sahnenin devamında beyaz bir elbise ve topuklu ayakkabılarla şık ve 
bakımı bir kadına dönüşen Carrie'nin önünde hemen bir taksinin durduğu gösterilmektedir. Bu durum, film genelinde de hâkim olan yönetmenin kadına yönelik bakış açısının onun cinsel ve tüketici kadın kimliğinden bağımsız olmadığının bir göstergesidir. Kadının güzel olması ancak onun şık ve cinselliğini ifade eden giyim kalıplarıyla sağlanmaktadır. Kadına insan olması nedeniyle değil, şık ve güzel olması koşuluyla değer verilmektedir. Bu bakış açısı ise, süper kadın kimliğinin bir niteliği olarak dikkat çekmektedir.

Filmin başından sonuna kadar tüketim ürünlerine ait marka isimlerinin sıkça kullanıldığı, karakterlerin tanınmış markalara ait ürünleri kullandığı ve reklam unsuruna sıkça yer verildiği görülmektedir. $\mathrm{Bu}$ anlamda film, tüketim kültürü ve bu kültüre ait markaları izleyiciye bir yaşam biçimi olarak sunmaktadır. $\mathrm{Bu}$ yaşam biçiminin vuku bulduğu mekânlar ise şüphesiz alışveriş merkezleridir. Tüketim toplumlarında alışveriş merkezleri, kadının kimliğini şekillendiren yeni kamusal mekânlar olarak öne çıkmaktadır. Evle özdeşleşen eş, anne ya da ev kadını kimliklerinden sıyrılmaya çalışan kadın, alışveriş merkezleri aracilığıyla kendine yeni bir kimlik edinme şansı yakalamaktadır. Boş zaman, eğlence ve tüketimin mekânı olan alışveriş merkezleri kadınların davranış kalıplarını belirleyerek kimliklerinin tanımlanmasına olanak sağlamaktadır. Özellikle satın almaya yönelik davranış kalıpları kadınların kamusal alanda kendilerini en kolay yoldan ifade etmelerini sağlayarak tüketici kadın kimliğinin tanımlanması noktasında iş görmektedir. Dahası, onu tüketici sınıfı içinde de bir yere yerleştirmektedir.

Filmde kapitalizmin yarattı̆ı tüketici kadın kimliği Samantha karakteri üzerinden sunulmaktadır. Samantha hem bedensel hem de cinsel hazları hayatının merkezinde tutan bir karakterdir. Bedensel olarak genç ve güzel olabilmek, cinsel açıdan ise cazibesini koruyabilmek adına kapitalist sistemin kadınlara dayattığ birtakım normları itinayla yerine getirmektedir. Yaşlanma karşıtı ilaçlar, cinsellik temalı kremler, formda kalmayı sağlayan beslenme düzeni ve cinselliği ön plana çıkaran giyim tarzıyla kapitalist sistemin yarattığ1 tüketici kadın kimliğinin somut bir örneğini sunmaktadır. Filmde Samantha'ya ait şu sözler de bu görüşü destekler niteliktedir; "Bižm yaşımı̊daki kadmlar vitaminler ile dalga gecmemelidir. Çok yakında bana teşekkeür edeceksiniz. Menopoz. labirentinde en önde ben gidiyorum. Vitaminlerim, melatoninli uyku bantlarm, doğala özdes östrojen kremim, Progesteron kremim birazda testestoron desteğiyle..." Görüldüğ̈ üzere, Samantha karakteri üzerinden kadın, erkek hazzının nesnesi olarak bedeniyle ve cinselliğiyle kurgulanmaktadır.

Filmde, Samantha dışında, diğer karakterlerinde tüketici kadın kimliğini desteklediği görülmektedir. Özellikle karakterlerin lüks tüketim ürünlerine olan merakı ve marka düşkünlüğü tüketici kadın kimliklerinin ön plana çıkmasına neden olmaktadır. Dış görünüsse ve güzelliğe yönelik ortaya çıan bu kimlik, Feminist hareketin yıllarca mücadele ettiği konuların da başında gelmektedir. Feministler, tarihsel süreçte değişen kadın giyim pratiklerini gündeme getirseler de kadının giyim şekli konusunda tam olarak ortak bir karara varamamışlardır.

\section{Abu Dabi / Sosyal Hayatta Kadın Kimliği}

Karakterlerin Abu Dabi'ye yaptıkları seyahat hem karakterlerin hem de seyircinin yeni bir kadın kimliğiyle tanışmasına neden olmaktadır. Bu kadın kimliği, alışılagelmiş batılı kadın kimliğinden ve onun temsil ettiklerinden oldukça uzak doğulu bir kadın kimliği olarak kurgulanmıştır. Daha yakından bakıldığında, aslında bu kimliğin ne tam anlamıyla batılı, ne de tam anlamıyla doğulu olmadığı; arada kalmışlığın bir temsilini sunduğu görülmektedir. Çünkü bu kadın kimliği dış görünüşü ve toplumsal yaşamdaki konumuyla doğulu kadın kimliğinin bir parçası iken; özünde özgürlüğü ve modernliği temsil eden batılı kadın kimliğini taşımaktadır. Bu durum, kadın kimliklerinin oluşumda içinde bulunulan mekânın önemini bir kez daha gözler önüne sermektedir. Özellikle toplumsal yaşamın icra edildiği kamusal mekânlar, kadınların kim olduklarından çok kim olmaları gerektiği üzerinde belirleyici rol oynayarak kadınları dayatılmış kimlik kalıpları içine yerleştirmektedir.

Bu açıdan bakıldığında, filmde Abu Dabi’ye ait gerçek bir kadın kimliğinden bahsetmek bile neredeyse imkansızdır. Bu anlamda film, kadının Abu Dabi'deki sosyal konumunu gerçeğe uygun olarak temsil etmektedir. Filmde de kadınlar görmezden gelinmekte ve yok sayılmaktadır. Bu durum, özellikle batılı ve süper kadın kimliğini temsil eden karakterler için oldukça şaşırtıcıdır. Daha ülkeye gelir gelmez Miranda, ülke kadının giyim tarzını "karşı cinste cinsel istek uyandırmayacak şekilde giyinme zorunluluğu" olarak tanımlamaktadır. Abu Dabi'de kadınlar, Müslüman kadın kimliğine uygun olduğu düşünülen göz haricindeki bütün vücudu kapatan nikap ya da yüzün açıkta olduğu abaya adı verilen geleneksel kıyafetler giymektedirler. Abaya giyen kadınların güneş gözlüğü takmasını ise Miranda, genç Müslüman kadınlarn eski geleneklere yeni bir yorum getirmesi olarak yorumlamaktadır. Müslüman kadının tesettür giyim pratikleri 
kapitalizmin gelişmesiyle beraber değişim içerisine girmeye başlamıştır. Böylece moda olgusu ile beraber ivme kazanan tüketim ideolojisi Müslüman kadınların yaşam biçimlerinde de yeniliklere yol açmıştır.

Carrie Müslüman kadınların giyim tarzını ise şu sözlerle eleştirmektedir; 'Başımı kapatabilirdim ama şalın ă̆zımı kapatması beni rahatsız eder, sanki konusması yasak gibı". Carrie’ye göre peçe kadının susturulması anlamına gelmektedir. Bu durum filmde sıkça başvurulan bir metafor olarak iş görmektedir. Film içinde üçüncü kez kullanılan bu metafor, dünyanın neresinde olursa olsun kadının sesine tahammül edilememesini, sürekli olarak susturulmaya çalısıılmasını anlatmaktadır.

Abu Dabi'deki dini kaynaklı toplumsal kurallar bir yandan kadınların bedenine ait her türlü ayrıntıyı günah kabul ederek yasaklarken diğer yandan da dansöz kadınların eğlence mekânlarında karınları ve gögüsleri açıkta kalacak şekilde dans etmesine izin vermektedir. Şehirde sadece dansözlere tanınan bu ayrıcalık, kadının erkek hazzının nesnesi olduğunu göstermektedir. Filmde benzer bir sahne de sona doğru, karakterlerin havaalanına gitmek için taksi durdurmaya çalıştı̆̆ sırada görülmektedir. Carrie'nin burkalı olarak durdurmaya çalıştı̆ı hiçbir taksi durmazken, burkasının alıından bacağını göstermesiyle ilk taksinin durduğu görülmektedir. Kadının cinsel kimliğinin ön plana çıkarıldığı bu sahneyle aynı zamanda filmin New York' da geçen ilk sahnesine de gönderme yapılmıştır. Bu karşılaştırmayla ister doğu da ister batı da olsun erkeklerin kadınlara karşı bakış açısının her yerde aynı olduğu gösterilmeye çalışılmışıtır. Buna göre, kadının toplumsal yaşamda varlığını kanıtlamasının ancak cinselliğini kullanarak olabileceği vurgulanmışır.

Şehirdeki kadınları bizim kadınlarımız ve diğerleri olarak tanımlamaya yarayan bu yaklaşım kadının gerçek kimliğiyle bir özne olarak değil; erkekler tarafindan sahiplenilen ve buna göre değer kazanan bir nesne olarak konumlandığının göstergesidir. Filmde bu durumun bir başka temsil de karakterlerin otelde kendi soyadlarıyla değil de eşlerinin soyadlarıyla kayıt yapılmış olmasıdır. Buradan da anlaşılacağı üzere Abu Dabi'de kadın, kendi başına bir birey olarak değil, erkeğe bağımlı bir nesne olarak kabul görmektedir.

Diğer yandan, mekânın kimlikleri şekillendirdiğinden yola çıkarak Abu Dabi’nin de karakterlerin kimliklerini değişime zorladığı görülmektedir. Bu değişim, dışardan gelen bir zorlamanın sonucu olarak kendini ilk giyim-kuşam alanında göstermektedir. Karakterler giyim kuşamlarında New York'ta olduğu kadar rahat ve özgür değillerdir. Şehrin kuralları onların da givim şekillerine yansımaktadır. Karakterlerin özellikle kamusal alanda şehrin kurallarına uygun olarak giyindikleri görülmektedir.

\section{Abu Dabi /İş Yaşamına Ait Mekânlarda Kadın Kimliği}

Filmde Abu Dabi'de iş yaşamına ait mekânlar ve bu mekânlarda çalışan kadın kimliğinin temsili yok denecek kadar azdır. Karakterlerin şehre girişlerinde havalimanında çalışan burkalı Arap kadınlar görülmektedir. Samantha karakterinin valizinde bulunan hormon ilaçlarının güvenlik gerekçesiyle sorun yaratması üzerine burada çalışan Arap kadınların sinirli bakışları gösterilmektedir. Bu sahne Arap kadınların ülkelerine gelen yabancı, kendilerinden olmayan kadınlara bakış açısını yansıtmaktadır. Dini, kültürel değerleri gereği kendilerinden farklı olan, bu farklılığ da giyim-kuşam başta olmak üzere hayatının farklı alanlarına yansıtan diğer kadınların Arap kadınları tarafından ön yargiyla karşılandığı ve onaylanmadığı görülmektedir.

Filmde bu sahne dışında, Abu Dabi'li çalışan kadın karakterlere rastlanmamaktadır. Bu nedenle de Abu Dabi'li çalışan kadın kimliği ve bu kimliğin mekânsal inşasına ilişkin herhangi bir bulgu söz konusu değildir. Bununla birlikte, şehrin çalışan kadın kimliğine ilişkin bakış açısını ortaya koyan bazı göstergelere rastlanmaktadır. Örneğin, karakterlerden avukat olan Miranda başı polisle belaya giren Samantha'ya yardım etmek istediğinde resmi görevlilerin buna müsaade etmediği görülmektedir. Bu durum, bir avukat olarak Miranda’nın mesleki yeterliliklerinin şehirde kabul görmediğine işaret etmektedir.

Şehirde toplumsal yaşamda bile kadın kimliğinin baskılandığı, görmezden gelindiği düşünüldüğünde çalışan kadın kimliğine rastlanmaması oldukça doğaldır. Çalışan kadın kimliği, kadınların erkeklerle aynı hak ve özgürlüklere sahip olduğu kabul edilen, bu nedenle de iş hayatına katıldığı toplumlarda ortaya çıkmaktadır.

\section{Abu Dabi / Alı̧veriş Mekânlarında Tüketici Kadın Kimliği}

Dünyanın her yerinde 'moda' olarak sunulan kültürün öncelikli hedef kitlesini kadınlar oluşturmaktadır. Abu Dabi'li kadınlar da Müslüman kadın kimliğinin gereği vücutlarını örten tek tip kıyafetler giyseler bile tüm dünyayı saran bu kültürün bir parçası olmaktan geri durmamaktadır. Bedenlerini örten burkalarının altında New York'lu kadınları aratmayan lüks markalara ait kıyafetlerle tüketim kültürünün önemli bir parçası olduklarını göstermektedirler. Filmde, Abu Dabi'li kadınların karakterlere 
yardım ettikleri sahnede hem burkalarının altındaki son moda kıyafetlerle hem de yakından takip ettikleri New York gündemiyle herkesi şaşırtmaktadırlar.

Diğer yandan Abu Dabi'de karakterlerin tüketici kadın kimliğini tanımlamaya yaracak başka ipuçlarına da rastlanmaktadır. Örneğin, safariye çıktıkları sahnede, çölün ortasında en lüks markalara ait kıyafetlere gereksinim duyabilecek kadar kapitalizmin kölesi durumundalardır. Bu sahnede lüks markaların seyirciye özellikle gösterilmesi de bunun bir kanıtıdır. Yine, karakterlerin uçağa yetişmek için acele ettikleri bir başka sahnede de Charlotte karakterinin mevcut koşulları göz ardı ederek her şeye rağmen alışveriş yapmak istediği görülmektedir. Bu sahnede, kadınların tüketim çılgınlı̆ıııı zaman ve mekân tanımazlı̆̆ına vurgu yapılmaktadır. Dolayısıyla film, farklı coğrafyalarda yaşasalar bile kadınların tüketim kültürü ile iç içe olduğunu göstermektedir. Kadınların alışveriş yapmaktan haz almaları, güzel olmaya ve beğenilmeye karşı duydukları karşı konulamaz istek her iki coğrafyanın kadınlarını bir araya getirmektedir.

\section{Tartışma ve Sonuç}

Kadın, kimlik ve mekân ilişkisini Sex and the City 2 filmi özelinde inceleyen bu çalışma, kadın kimliğinin belirlenmesi noktasında mekânın önemine vurgu yapmaktadır. Mekân, özel ve kamusal alanlarda kadın kimliğinin belirlenmesi ve bu kimliklere uygun davranış kalıplarının geliştirilmesi noktasında oldukça önemli bir işleve sahiptir. Bununla birlikte, diğer yandan da kimlikler tarafindan şekillendirildiği görülmektedir. Özellikle kadın ve kimlik konulu tartışmalarda özel alan ve kamusal alan tartışmalarının gündeme geldiği; kadın kimliğinin özel alanın mekânsal temsili ev ile ilişkilendirildiği; kamusal mekânlardan ise çoğunlukla soyutlandığ fark edilmektedir.

Söz konusu filmde de kadın kimliğinin belirli mekânlar ve belirli tanımlamalar üzerinden temsil edildiği görülmektedir. Bu bağlamda filmde kadın kimliğinin temsil mekânları olarak başta New York ve Abu Dabi şehirleri ön plana çıkmaktadır. İlgili şehirler, sahip oldukları imajlarla kadın kimliğinin tanımlanmasında önemli bir rol oynamaktadır. Bu bağlamda New York batılı, özgür, güçlü kadın kimliğini tanımlarken; Abu Dabi ise geleneksel, bağımlı ve bastırılmış kadın kimliklerini tanımlamaktadır. Bu tanımlamalar, kadınların şehrin kamusal alanlarına erişiminin olup olmadığı, bu alanlarda özgürce davranıp davranamadığı, erkeklerle aynı haklara sahip olup olmadığı gibi şehrin kadınları baskılayan ya da özgürleştiren kuralları sonucu ortaya çıkmaktadır. Filme bu açıdan bakıldığında, New York şehrinde kadınların kamusal alanlara özgürce erişebildiği; erkeklerle aynı oranda kamusal yaşam alanlarında yer aldığı, herhangi bir kısıtlama ya da baskıya maruz kalmadığı görülmektedir. Filmde yer alan sosyal etkinlikler, davetler, yemek organizasyonları gibi sahneler de bunu kanitlamaktadır. Ancak Abu Dabi şehrinin kadınların kamusal alanlara katılımını kısıtladı̆̆ı, kadınların her zaman her yere özgürce gidemedikleri, şehrin kamusal alanlarında ancak belirli kurallar çerçevesinde var olabildikleri görülmektedir. Bu açıdan bakıldığında, filmde New York şehrinin hem işte hem de evde başarılı olan, çalışan ama evini de ihmal etmeyen, kendi ayakları üzerinde duran, bakımlı, güçlü ve özgür kadını tanımlayan süper kadın kimliğiyle örtüştüğü görülmektedir. Ancak karakterlerin Abu Dabi'ye yaptıkları seyahat ve sonrasinda gelişen olaylar incelendiğinde, aynı kimliğin Abu Dabi'de sürdürülemediğine ve zorunlu bir dönüşüme uğradığına tanık olunmaktadır. Nitekim filmde karakterlerin Abu Dabi seyahatinden sonra başka bir kimliğe evrilmeleri de bunun bir kanıtı durumundadır.

Aynı şekilde, şehirlere ait ev, iş ya da alışveriş mekânlarının da bulundukları şehirlerin imajlarından beslendikleri ve kadın kimliklerinin belirlenmesinde rol oynadıkları görülmektedir. Ev 'ev kadını', iş 'çalışan kadın' ve alışveriş mekânları da 'tüketici kadın' kimliklerinin şekillenmesinde önem arz etmektedir. Ancak bu anlamda var olan kalıplaşmış yargılar, filmde de aynı şekilde devam ettirilmiştir. Her ne kadar süper kadın kimliğine sahip olsalar da kadınların evde 'evin kadını' olarak yapmak zorunda oldukları bir takım görev ya da sorumluluklarının; iş yaşamında 'çalışan kadın' olarak maruz kaldıkları ayrımclık ve farklı türlerdeki şiddetin ve nihayetinde de tüketim toplumunun dayattı̆̆1 'tüketici kadın' kimliklerinin sadece New York ya da Abu Dabi’de değil; dünyanın hiçbir yerinde değişmediği görülmektedir.

Film, kadınların mekânlarla bağlantılı olarak ortaya çıkan 'anne', 'eş', 'çalışan' ya da 'tüketen' kimliklerinin çoğu zaman onları yeterince tatmin etmediğine; farklı yer ve zamanlarda bu kimliklerini sorgulamak zorunda kaldıklarına da dikkat çekmektedir. Daha çok çevresel faktörlerden kaynaklanan bu durum, kadınların sahip oldukları kimlikleri sorgulamalarına ve bu konularda ne kadar başarılı/başarısız olduklarına ilişkin kuşku duymalarına neden olmaktadır. Bu anlamda filmde de örneği sunulduğu üzere; bir anne anneliğini; eş eşliğini, çalışan da çalışanlığını sorgulayarak bir iç hesaplaşmaya gitmektedir. Oysaki bu sorgulamanın temel nedeni her alanda egemen olan ataerkilliktir. Kadının sahip olduğu kimliklere ilişkin 
tamlığa ulaşma duygusu ve bu duygunun her defasında ataerkil yapının duvarlarına çarpması bu sorgulamay1 beraberinde getirmektedir.

Diğer yandan, filmde ataerkil bir yapıda örgütlenen tüketim kültürünün kadın bedenini hedef aldığg konusuna da önemli bir vurgu yapılmaktadır. Kadının genç ve bakımlı olması, bedenini ön planda tutması, bedeniyle erkek hazzının bir nesnesine dönüşmesi hem ataerkil bir sisteme hem de kapitalizme hizmet etmektedir. Kadının her alanda bedeniyle var olmaya çalışması ya da bedeniyle yok olmaya mahkûm olması kapitalizmin dayattığı tüketim kültürü kadar içine hapsolduğu mekânlarla da ilişkili bir durumdur.

Ayrıca filmin taşıyıcı annelik, gay düğünleri ve lezbiyen ilişkileri gibi radikal feminist paradigmaya ilişkin düşüncelere de yer verdiği görülmektedir. Oysaki film görünürde kadınlara özgürlük vadeden, toplumsal cinsiyete ilişkin tabuları yıkan, güçlü ve özgür bir süper kadın kimliğine ilişkin algısının aksine, alt metinde stereotipleşmiş kadın karakterlerin ayrımcllğ̆a uğramış, baskılanmış ve bastırılmış bilinen hikayesini anlatmaktadır.

Bu çalışma sonucunda, kadınların sinema alanında yönetmen ve senarist olarak daha fazla yer almaları gerektiği anlaşılmaktadır. Kadın yönetmenler ve senaristler, kadınsı bakış açılarını filmlerine yansıtarak, erkek yönetmenlere karşı bir dil oluşturmalıdır. Kadınsı bakış açısının oluşmasında aşağıda yer verilen öneriler yol gösterici olabilir.

1. Sinema filmlerinde yer alan kadın temsilleri, kadının bedeninden ziyade akli yeteneklerine odaklanmalıdır.

2. İş yaşamında kadın temsillerinde kadın susturularak değil, başarıları ile ön plana çıkarılmalıdır.

3. Tüketim kültürünün kadına biçmiş olduğu güzel kadın imgesi, kadının kendisini boş ve gereksiz işlerle meşgul etmesine neden olmaktadır. Sinemada kadın izleyicilerin öykündüğü bu kadın karakterler, kapitalist sistemin işleyişine hizmet etmektedir. Filmlerde cinsiyetçi bu bakış açısı terk edilmelidir.

4. Filmlerde erkeğin her zaman haklı olduğu anlayış yerine onların da hata yapabileceğine yer verilmelidir.

\section{Etik Beyan}

"Kadın Kimlik Mekân: Sex And The City 2 Filminde Süper Kadın Kimligü’ başlıklı çalışmanın yazım sürecinde bilimsel, etik ve alıntı kurallarına uyulmuş; toplanan veriler üzerinde herhangi bir tahrifat yapılmamıs ve bu çalışma herhangi başka bir akademik yayın ortamına değerlendirme için gönderilmemiştir. Bu araştırmada doküman incelemesi yapıldığından etik kurul kararı zorunluluğu bulunmamaktadır.

\section{Kaynakça}

Assmann, J. (2001). Kültuirel bellek: eski yülesek kültürlerde yaž, haturlama ve politik kimlik (Çev: A. Tekin). İstanbul: Ayrintı Yayınları.

Best, S. ve Kellner, D. (1998).Postmodern teori: eleștirel sorușturmalar (Çev: M. Küçük). İstanbul: Ayrıntı Yayınları.

Castells, M. (2008). Enformasyon çağı: ekonomi, toplum ve külttür (Çev: E. Kiliç). İstanbul: İstanbul Bilgi Üniversitesi Yayınları.

Davidoff, L. (2016). Feminist tarih yažmmnda smenf ve cinsiyet (Yay. Haz: A. Durakbaşa) (Çev: Z. Ateşer ve S. Somuncuoğlu). İstanbul. İletişim Yayınları.

Davis, F. (1997). Moda, kültuir, kimlike (Çev: Ö. Arıkan). İstanbul: Yapı Kredi Yayınc1lık.

Donovan, J. (2014). Feminist teori: entelektiuel gelenekler (Çev: A. Bora- Meltem A. Gevrek- F. Sayılan). İstanbul: İletişim Yayınları.

Erdoğan, İ. (2012). Pozitivist metodoloji ve ötesi: araşstrma tasarmlar, niteliksel ve istatistiksel yöntemler. Ankara: Erk Yayınları.

Everett, J. J. ve Martino, S. M. (2014). Superwomen on the big screen: How media portrayals affect female viewers. Journal of Behavioral Health, 145-148. DOI: 10.5455/jbh.20140604080944

Hall, S. (1998). Eski ve yeni kimlikler, eski ve yeni etniklikler. Anthony D. King. (Der.) Kültür Küreselleșme ve Dünya Sistemi: Kimlik Temsilinin Că̆daş Koşullar içinde(Çev: G. Seçkin ve Ü. H. Yolsal) (ss. 63-90). Ankara: Bilim ve Sanat Yayınları.

Haralovich, M. B. ve Press, A. L. (2012) New feminist television studies: queries into postfeminist television. The Communication Review, 15(3), 163-166.

Kandiyoti, D. (2011). Cariyeler, bacllar, yurttaşlar: kimlikler ve toplumsal dönïşümler. İstanbul: Metis Yayınları.

Kellner, D. (2001). Popüler kültür ve popüler kimliklerin inşası (Çev: G. Seçkin). Doğu Batı, 4(15), 195-226.

Kim, S. (2008) Feminist discourse and the hegemonic role of mass media, Feminist Media Studies içinde, 8(4), 391-406.

Martino, S. ve Lauriano, S. (2013). Feminist identity and the superwoman ideal. Journal of Behavioral Health, 2(2), 167172.

Özden, Z. (2004). Film eleștirisi: film eleștirisinde temel yaklaşımlar ve tür filmi eleștirisi. İstanbul: İmge Yayınları. 
Özyurt, C. (2005). Küreselleşme sürecinde kimlik ve farkhllaşma. İstanbul: Açılım Kitap.

Rousseau, J. J. (2018). Emile: Bir çocuk büyzüyor (Yay. Haz: Ü. Akagündüz). İstanbul: Selis Kitaplar.

Ryan, K. ve Kellner, D. (2010). Politik kamera: çağdass hollywood sinemasmmn ideolojisi ve politikasi. (Çev: E. Özsayar). İstanbul: Ayrintı Yayınlar1.

Sennett, R. (2011) Ten ve taş: Batı uygarlı̆gnda beden ve şehir (Çev: T. Birkan). İstanbul: Metis Yayınları.

Steeves, H. L. (1994). Feminist teoriler ve medya çalışmaları. İçinde M. Küçük (Der. ve Çev.). Medya, İktidar, ideoloji (ss. 105-168). Ankara: Ark Yayınlar1.

Van Zoonen, L. (1997). Medyaya feminist yaklaşımlar. S. İrvan (Der.). Medya Kültür Siyaset (ss. 467-511). Ankara: Ark Yayınevi.

Weeks, K. (2012). Feminist öznelerin kuruluşu (Çev: İ. Özküralpli). İstanbul: Otonom Yayınları.

Woolstonecraft, M. (2007). Kadın hakelarmin gerekçelendirilmesi (Çev: D. Hakyemez). İstanbul: Kültür Yayınları.

\section{EXTENDED ABSTRACT}

Identity is a sense of perception that is imposed by the society and internalized by individual who accepted it. It is in the problematic field of the feminist paradigm in which the man has a privileged identity and the woman is surrounded by identity elements with lower position than men and less rights than men have. This study tries to analyze the identity of the woman with the identity of "Super Woman" by prioritizing the concept of space. Capitalist culture responded to liberal feminist media studies with the Super Woman identity. Accordingly, Super Woman is designed as a good mother or wife, a successful business woman and women who care about her body. This kind of woman identity which increased their workload in the business life has also caused women be the most important target audience of the capitalist culture by imposing the idea that they should maintain their beauty in all the times. This study aims to conduct a qualitative analysis of the four female characters through the identity of Super Woman in Sex and the City 2, the movie directed by Michael Patrick King and released in 2010. The study handles the relationship between the woman identity and space in the movie based on feminist media studies. In this study, superwoman identity was evaluated within the framework of woman-identity and space relations. In this evaluation, the cities of New York and Abu Dhabi were the main places that determine women's identity and their identities and the ways of behaviour and identities in the two different cities were examined. Young, beautiful, well-groomed, successful at home and work, these women represent the superwoman identity. However, this identity of women is an identity that occurs depending on the place. The journey in the movie that begins in New York City extends to Abu Dhabi and a return to New York is, in fact, a spiritual journey of the women in which their identity is transformed throughout the changing places. This journey that women started with the superwoman identity ends with Castells' legitimizing identity and evolves to the identity imposed by the social structure. This situation is supported by the use of different cinematographic elements such as mise-en-scene, optical angle, and positioning in the movie. The women's identity is represented through certain places and definitions in the movie. In this regard, New York and Abu Dhabi are the representative places of women identity. These cities have a significant role in defining women's identity with their images. In this context, New York represents western, free, strong woman identity; Abu Dhabi represents traditional, dependent and suppressed women's identities. These definitions are given about city's rules that suppress or liberate women, such as whether women have access to public areas in the city, whether they act freely in these areas, whether they have the same rights as men have. From this point of view, women in New York can freely go to public areas, have the equal right in public areas with men and are not subject to any restrictions or pressure in society. Social events, invitations, food organizations in the movie support this idea. However, it is seen that women in Abu Dhabi have some restrictions in the participation of public areas, they cannot always go anywhere freely, and they can appear in the public areas of the city if they obey certain rules. In this way, it is seen that the New York City can be associated with the independent, well-groomed, strong, and free superwoman identity, who is successful at work and at home, who works but does not neglect her housework. However, when the characters' travel to Abu Dhabi and the events that occur afterwards are examined, it is observed that the superwomen identity cannot be maintained in Abu Dhabi and that it has undergone a compulsory transformation. Nevertheless, the identity transformation of these characters after a journey to Abu Dhabi is definitive proof of this. In the same way, it is seen that the city's home, business or shopping places are shaped by the images of the cities where they are located and they play a role in determining women's identities. Houses, business life and shopping malls produce the woman identities of 'housewife', 'businesswoman' and 'consumer respectively. These stereotypes are reflected in the movie in the same way. It shows that women can not be free from their duties and responsibilities are given by society neither in New York nor in Abu Dhabi. Regardless of the space, there is no way to escape 
from housework as an angel in the house at home, gender discrimination at work, female consumer identity imposed by consumerist society for women. The movie points out that these identities such as "mother", "wife", "businesswoman", and "female consumer" which are created by the space are deficient and these identities are questioned at different times and places. This situation, which is mostly caused by environmental factors, causes women to question their identities and have doubts about success criteria in these fields. As a mother questions the concept of maternity, a wife questions the concept of wifehood and an employee questions the concept of being an employee, they are in the state of inner conflict. However, the main reason for this questioning is the patriarchy that dominates every social field. What led women questioning is that the desire for fulfilling the sense of identity is prevented by the patriarchal society. On the other hand, an important emphasis is placed on the issue that the consumer culture, which is organized in a patriarchal structure, targets the woman body. The fact that the women is young and well-groomed, expose her body and transforms her body into an object of male gaze serves both a patriarchal system and capitalism. The fact that the woman tries to exist utilizing her body in every field or is destined to vanish utilizing her body is related to space as much as the consumption culture imposed by capitalism. 